\title{
Interregional Variations In Manufacturing Investment
}

\author{
Albert L. Winkler*
}

\section{INTRODUCTION}

Investment behavior has been an empirically elusive phenomenon in both temporal and spatial investigations. Although a variety of conceptual apparatuses and data sources have been employed to facilitate an understanding of variations in investment, the results have been less than satisfactory.

The purpose of this paper is to explore the potential of an alternative investment model formulation which incorporates theoretical constructs from location theory, regional growth theory, and theory of the firm in an interregional model of manufacturing investment. An ancillary purpose is to formulate some empirical measures of investment determinants, particularly in the area of expected rates of return.

\section{MODEL FORMULATION}

The focus of this investigation is on the rate of net investment as defined by a net change in capital measured by net investment divided by capital stock. Since such a measure is a flow concept, the analysis is essentially concerned with a component of growth. As such it is related to prior studies of interregional factor movements. [See 5 and 13].

An investment decision is in essence a location decision. Hence, the concepts of location theory apply to the hypotheses formulation of the model under consideration.

Integrating the theory from these various branches of economics can be simply introduced by considering a synthesizing agent in the form of profits. Representing a residual, the difference between total revenue and total cost, profits tie together the product market and the factor market. Since pure or economic profits tend to zero in equilibrium, we can consider profits in an absolute sense only in the movement toward equilibrium, a process in which resource reallocations and transformations occur. Consideration of factor and product movements involve transport costs and location decisions.

In relation to investment theory profits are assumed to motivate invest-

\footnotetext{
*The author is associated with Kansas State University. The research was supported by Kansas State University and the National Defense Education Act. Professor M. Jarvin Emerson of Kansas State University provided research and editing assistance.
} 
ment. The simultaneous relationship of profits to investment and to the dynamics of factor movements and transport cost consideration comprises a strong connecting link between investment theory and location theory.

Also several empirical studies based on differing theoretical frameworks influenced the development of the model. These included Eisner [16], Borts and Stein [5], Romans [13], Scully [21], and Sherman [14].

The hypotheses to be tested are as follows:

The rate of investment $=f_{1}$ (expected rate of return)

$+f_{2}$ (uncertainty in investment)

$+\mathrm{f}_{3}$ (resource misallocation)

$+\mathrm{f}_{4}$ (agglomeration)

$+f_{5}$ (government expenditures)

$+f_{6}$ (amenities)

$+\mathrm{f}_{7}$ (distance)

The model assumes that the capital market is highly mobile with no major institutional restrictions to the movement of capital among states.

\section{THE VARIABLES}

Investments Rates, I

The investment rate for each state was calculated from the 1963 Census of Manufactures and the 1958 Census of Manufactures data. The method used was to adjust capital stock figures taken from the 1958 Census of Manufactures by adding net investment to determine the capital stock figures for each year of the investment study time period, 1954-1964. Then by means of net investment/capital stock a rate of investment was computed for each year, from which three year averages were taken to reduce instability in the model by lengthening the time period.

Net investment in the process was determined by computing the depreciation rate for 1957, and assuming that rate of depreciation constant to calculate depreciation.

\section{Trend Rate of Return, TR}

The rationale embodied in the first independent variable is twofold. In a trend of rising rates of return, it is clear on the one hand that we may expect expanding investment rates $[19$, p. 78$]$. In this context, the rising trend of returns can positively affect both expectations of future returns and the supply of internal sources of funds resulting in an expected positive correlation between the investment rate and the trend of returns. The return trend then affects both the demand for and the supply of investment respectively.

On the other hand where certain types of technological change occur in a dynamic competitive situation, a declining trend of return rates may signal the need for strategic investment decisions either in current plants or in opening new plants if the firm or industry is to be competitive. Assuming the economy is operating near equilibrium, then a significant 
decline in the rates of return in one area implies that the trend of returns may be relatively better in other areas, possibly due to innovation in those areas. The probability that a firm will introduce a new technique (investment) has been shown to be an increasing function of the proportion of firms already profit using it [20, p. 763]. An important input into the firm's decision process is evidence that as more firms adopt the new technique they subsequently enjoy a higher rate of profitability while firms staying with the old techniques experience profit depressing competition. Thus when a declining trend in return rates motivates investments we expect the fall in returns to induce higher rates of investment yielding a negative correlation between investment and the return trend. In summary, the regression coefficient for the trend variable may be either positive or negative.

Statistical measures of the return rate trend were calculated from data obtained from the 1963 Census of Manufactures by States and the 1958 Census of Manufactures. Return figures were calculated by subtracting both payrolls of all employees and depreciation allowances from value added by manufacturers for each state, the data taken from both sources. The rate of return was then derived by dividing returns by capital stock figures for that year, where annual capital stock figures were computed by adjusting annually with net investment the gross book value of manufacturer's plant and machinery on December 31, 1957 as quoted in the latter source.

Letting the rate of return be represented by $\mathrm{RR}$, the year by $\mathrm{t}$, and capital stock by $K$, the trend variable can be represented by $R R_{t}-R R_{t-1} / K_{t}$. Three year averages of the RR trend were tested in separate models for each year.

\section{Rates of Return, RR}

Much the same rationale embodied in independent variable (1) is applicable to independent variable (2), the rate of return. That is, differences between states of rates of return may positively affect differences in either the demand for investment or the supply of investment through the effects respectively on expectations and supply of internal funds, or the impact may be felt negatively with regard to the strategic competitive position of the firm.

\section{Standard Deviation of Returns, SD}

The standard deviation of earnings is a third type of measure of the behavior of earnings. Since uncertainty cannot be measured in a pure sense, the standard deviation is a proxy for a measure of risk [2, p. 45]. It is another means of estimating average expected future earnings by extrapolation of past experience and the use of judgment based on knowledge of segments of the market and reflecting circumstances of the market as a whole.

Profit fluctuations are said to influence the industry's approach to investment as "A relatively high profit margin is a favorable characteristic, a low profit margin, unfavorable. Wide fluctuations in profit margins are likewise unfavorable," [1, p. 421]. From this we may expect a negative 
relationship between independent variable three and the dependent variable. Empirical studies in the financial markets have confirmed this theoretical reasoning in that area. One of these studies compared investments in common shares to earnings behavior for both IBM (International Business Machines) and GM (General Motors). The rising trend in earnings for IBM was much more rapid and more stable (deviations from the earnings trend was much less) than that of GM while the shares of IBM sold at 35 times earnings compared to 18 times earnings for GM [22, p. $335]$. We may thus expect the demand for investment to be stronger in those states with smaller deviations of earnings from their trend line, or a negative coefficient for the standard deviation of earnings.

Again we must consider the strategic role of the standard deviation of returns in determining investment. In reference to the studies of Sherman and Osborn $[14,11]$ in which the standard deviation and uncertainty of returns respectively were indicated to decrease with the size of the business unit we can also expect relatively large deviations of returns to increase the demand for investment. In stituations where small size or limited diversification of the firm limits stability of earnings we may rationally anticipate a positive sign for the coefficient of the standard deviation.

\section{Wage Rate, WR}

The wage rate was found important by Romans in applying the neoclassical model of long-run equilibrium growth to explain regional distribution of investment expenditures. The degree to which wages and salaries of non-agricultural workers was found unequal between regions was considered an indication of the degree of resource misallocation between regions [13, pp. 85-90; also see 5, pp. 66, 75]. The lower the wage level for a region, or state as compared to other states, the higher we may expect the level of investment to be for that state [13, p. 96]. In this case, we may expect the relationship between the wage rate and the investment rate to be negative.

Another view, expressed by Myrdal, is that the free play of market forces creates an inherent tendency to perpetuate regional inequalities. In this view, increased demand (from high labor incomes) in the centers of investment expansion is considered to spur multiplied rounds of investment and demand $[10$, pp. 6, 28, 53]. Consequently we could also expect positive coefficients for the wage rate. Borts and Stein did not find, in their study, that Myrdal's theory was compatible with the evidence for the United States [5, p. 4]. Romans' study found major evidence of agreement with Myrdal's theory in only one major region in the U.S., the Great Lakes Region. This region, which had the highest labor income, also had a significantly higher investment rate than other regions [13, p. 97]. Coefficients may be positive or negative, but for the U. S. as a whole, ex ante information favors the positive.

The source of data for the wage rates in this study is the gross average hourly earnings of production workers on manufacturing payrolls taken from Employment and Earnings Statistics for States, 1939-1963, United States Department of Labor. 
Supplies of Labor, SL and Manufacturing Labor, ML

The supply of labor and manufacturing employment in a region were found by Borts and Stein to be related to rates of growth [5, Chs. 4-6]. Romans likewise found secular investment in a region related to both the labor supply and employment. He states "Changes in the labor supply are more likely to be disequilibrating than changes in capital," [13, p. 90]. Hoover wrote that even if labor-cost differences do not exist some Locations for Investment would have a more attractive labor supply from the standpoint of low cost production. The size of the labor force group within commuting distance from production points involves the principle of "massing of reserves" which affects the economy of the local labor force group [8, pp. 111-115]. The number of employees in manufacturing in a state serve as proxy variable for agglomeration economies to manufacturers. Part of these economies is a reduction of uncertainty.

From the above theoretical relationships, the supply of labor measured as employees in manufacturing can be expected to have positive regression coefficients in explaining investment. Empirically, this may not be a relevant assumption, however, since we cannot assume a static, purely competitive model in the real world. Specifically, we cannot assume other things equal, particularly wage rates among localities. It has been shown that city size has a major impact upon wages with each (major) region of this country, no matter what kind of labor is being hired. Higher wage rates are found in larger cities [3, p. 245]. Such differentials in wage rates between sizes of cities, for comparable jobs, have run as high as 63 percent in the past $[3$, pp. 245,246$]$.

It is not clear what the reasons are for differentials of such magnitude. Some economists have considered the effect of labor union organization in large cities as significantly affecting urban-rural wage differentials. A "labor market disequilibrium" between small towns and large cities has been postulated by one writer as being due to a totally different reason: "Capital is scarce relative to labor in small towns, keeping wages low; capital is abundant relative to labor in big cities, pushing wages up," [7].

Figures used for the supply of labor in this study were those given, by states for employees in non-agricultural establishments from the Census of Manufactures by States, 1963. Data for employees in manufacturing was taken from the same source.

\section{Capital-Labor Ratios, K/L}

The usefulness of capital/labor ratios in explaining investment is embodied in the neoclassical school of growth and investment theory. Numerous studies, a few of which have been referred to, have attested to this relationship. Basically, under the assumptions given for the neoclassical framework, capital would move to regions offering higher rates of return. Interregional factor mobility should eliminate differences in rates of return and thereby always be equilibrating where factors respond to economic (i.e., profit) incentives [13, p. 89]. As indicated above with reference to Funchs, where capital/labor ratios are low, wages are relatively 
low. Both the capital and labor markets are in disequilibrium simultaneously; therefore they are interdependent. In the tendency to move to equilibrium, capital will flow to the low capital/labor ratio areas as firms adjust their capital-labor proportions to the least-cost combinations. In this adjustment process, they are equating the slopes of the iso-cost and isoproduct curves while increasing returns to both capital and labor.

Anticipating a movement of capital to low capital-labor ratio states implies a negative sign for the respective regression coefficient. Exceptions to this, with reference to Myrdal's theory as discussed, would be a special case. The capital/labor ratios were calculated from the data taken from the respective sources indicated above for capital stock figures and the supplies of labor both by states.

\section{Elasticity of Capital with Respect to Labor, $\mathrm{e}_{\mathrm{k} 1}$}

The elasticity of capital with respect to labor, $\mathrm{e}_{\mathrm{k} 1}$, in effect is an indication of the comparative mobility of factors and innovative ability of managers for the respective states in the years prior to the period of investment. The percent change in capital/percent change in labor indicates the relative rate at which these factors have been adjusting. Borts and Stein show ". . . that capital imports in subsequent periods depend upon the value of the elasticity of substitution," [5, p. 144]. A change in the elasticity of substitution is also an indication of how technology has changed (the rate of innovation) since it is one of the ways in which technology affects the iso-product curve [15, p. 387].

The same rationale that applies to the capital-labor ratios is relevant to the $e_{\mathrm{k} 1}$. That is, negative coefficients would be a special case and could be explained in the Myrdal context. Sources of data were again the same as those for the capital and labor supply figures.

\section{Defense Expenditures, DE}

In recent years much attention has been commanded by the regional impact of defense expenditures as an economic issue. This type of government expenditure can be considered to increase investment in certain regions not only through its impact on regional demand through the multiplier, but the initial impact of such expenditures on investment may be both dramatic and exogenously determined by noneconomic factors. In his study of this topic for the Korean and post-Korean era, Bolton pointed out that "... in the need to develop entirely new weapons and technical processes, the factors shaping the distribution of contracts became much more subtle than the mere existence of capacity, since new capacity had to be created," [4, p. 2]. A measure of this type of government expenditures can then add to the explanation of investment among the states provided by the variables measuring performance of the private economy. The rate of defense expenditures to capital stock was used.

With the introduction into the model of a measure of influence of the government sector on investment we may note that the government role in the economy has been increasing rapidly since 1930. Public expenditures 
by 1967 had reached 22 percent of GNP, of which federal expenditures were about 50 percent, with defense expenditures comprising about 80 percent of the federal outlays [12, pp. 98-102]. Defense expenditures can be expected to initially increase directly the demand for investment, indicating that a positive regression coefficient may be anticipated. Data for defense expenditures was taken from Bolton's study, Defense Expenditures and Regional Growth [4, Appendix A-1].

\section{State and Local Government Expenditures, S \& L}

State and local government expenditures, which comprise about onehalf of public expenditures, can be related to the dependent variable with basically the same rationale as was used for defense expenditures. Again a positive regression coefficient is anticipated. The source of the data was The Statistical Abstract of the United States, 1961, Bureau of the Census. Three year average figures were used for both defense and state and local government expenditures to reduce the instability in the model. State and local expenditures were also divided by capital stock to relate them to the investment rate.

\section{The Temperature Variable, TP}

In considering the temperature variable one can reason that climate is important in the potential investor's decision regarding the location of the investment. In Greenwood's studies in which he found this variable highly significant in interregional migration, he considered not only sunshine itself as being an attractive force but also that the cost of living is less in a more temperate climate. Investors can be expected to consider these factors not only for their own benefit, but also in their awareness that location preferences of key management and labor personnel are likely to be similarly influenced by warm climate. Thus, it is expected that, ceteris parabis, the greater the temperature of state $\mathrm{j}$ relative to state $\mathrm{i}$, the greater the investment in state $\mathrm{j}$ relative to state $\mathrm{i}$. Hence, positive regression coefficients can be anticipated.

The mean yearly temperature of each state was calculated from the "normal monthly average temperatures of selected cities" from The Statistical Abstract of the U.S., 1965.

The independent variables outlined above were those which produced the highest $R^{2} \mathrm{~s}$ while at the same time yielding the most significant regression coefficients in one or more of the years for which regressions were made. The years indicate the year of the median rate of investment in the dependent variable, which is three year average rates of investment.

Where three year averages were used for independent variables the averages were for the three year periods prior to the median year of the period for the dependent variable. The rationale for this is, of course, that investors base their expectations and hence their decisions upon past information, i.e., that subjective evaluations are founded largely on objective evaluations. 


\section{FORM OF THE VARIABLES}

Three year averages of the dependent variable, the rates of investment were used to reduce extreme annual variations in the data. Again the mean year of the investment three year period was used to identify the time period of investment. The time periods for the respective independent variables used were time periods beginning the year previous to the mean year of the investment time period.

The averaging method, in place of lagged variables, also reduced autocorrelation. The independent variables represented in average time periods were confined to those which measured behavior of returns and government expenditures.

\section{THE REGRESSION MODEL}

A basis is provided in the previous discussion for testing the hypothesis suggesting a least squares regression equation in the form:

$\mathrm{I}_{\mathrm{ij}}=\mathrm{a} \pm \mathrm{b}(\mathrm{TR})_{\mathrm{ij}_{-n}} \pm \mathrm{c}(\mathrm{RR})_{\mathrm{ij}_{-n}} \pm \mathrm{d}(\mathrm{SD})_{\mathrm{ij}_{-n}} \pm \mathrm{c}(\mathrm{WR})_{\mathrm{ij}_{-1}}$

$\pm f(S L)_{i j_{-n}} \pm g(M L)_{i j_{j} 1} \pm \mathrm{h}(\mathrm{K} / \mathrm{L})_{\mathrm{ij}_{-1}} \pm \mathrm{k}\left(\mathrm{e}_{\mathrm{k} 1}\right)_{\mathrm{ij}-1}$

$\pm 1(\mathrm{DE})_{\mathrm{ij}-\mathrm{n}} \pm \mathrm{m}(\mathrm{S} \& \mathrm{~L})_{\mathrm{i} \mathrm{j}_{-\mathrm{n}}} \pm \mathrm{n}(\mathrm{TP})_{\mathrm{ij}}+\mathrm{r}$

where

$i$ represents the state, $\mathrm{j}$ the year, and $\mathrm{n}$ the number of years averaged.

Let

$\mathrm{I}=$ three year average annual rate of net investment/capital stock by state.

$\mathrm{TR}=$ average trend of the rate of return on capital for 3 year period.

$\mathrm{RR}=$ average rates of return for 3 year period.

$\mathrm{WR}=$ wage rate of non-agricultural workers.

$\mathrm{SL}=$ the supply of labor defined here as employees in non-agricultural establishments.

$\mathrm{ML}=$ manufacturing labor employed indicated as employees in manufacturing.

$\mathrm{K} / \mathrm{L}=$ the capital-labor supply ratio.

$\mathrm{e}_{\mathrm{k} 1}=$ the elasticity of capital with respect to labor.

$\mathrm{DE}=$ defense expenditures/capital stock.

$\mathrm{S} \& \mathrm{~L}=$ state and local government expenditures/capital stock.

$\mathrm{TP}=$ the mean annual temperature by states.

$r=$ a random error term.

In addition in certain regression equations dummy variables were introduced to reflect certain regional or transportation characteristics. They are defined as: 
$\mathrm{S}=$ a dummy South or non-South variable used to determine if the independent variables accounted for all the differential between regions [21]. Dummy $=1$ if the state is in the South; Dummy $=0$ if the state is not in the South.*

$\mathrm{C}=$ a dummy coastal or non-coastal variable to determine if the independent variables measured all the effects of transportation cost differentials between states which do not have access to major waterways. Dummy $=1$ if the state is on a major waterway. Dummy $=0$ if the state is not on a major waterway.**

\section{EMPIRICAL RESULTS}

Table 1 summarizes the regression results for the years 1959 and 1960 as the median years of three year average rates of investment.

In interpreting the results presented in Table 1, it may be said that for the 1959 investment time period a 7.6 percent difference among states in their investment rate was associated with a 1 percent difference among states in $\mathrm{TR}_{3}$, the three year average trend in rates of return. The coefficients of all the independent variables that entered the stepwise regression model in the respective years may then be interpreted in that manner. This type of interpretation is that used by Borts and Stein in their study of regional economic growth [5, p. 69].

The results summarized in Table 1 indicate that the independent variables measuring the behavior of the rates of return, particularly the TR and $R R$ variables, were significant in explaining differences among states in the rates of investment. This suggests that the theory of the firm, which considers both demand and supply determinants of profits, can be empirically represented in an investment model.

However, the signs of the coefficients of rates of return were opposite for the two years. The sign of rates of return was negative in 1959, the Kennedy presidential election year, an indication that profits influence was mainly due to strategic competitive considerations in that year when the economy and economic policy were major campaign issues. The positive coefficients in 1960 imply that when conditions are more uncertain (standard deviation of returns was significant in 1960) the influence of the trend of returns is felt more in its role of supporting internal funds and investor confidence. The "new economics" was introduced during that period.

Of particular interest are the results obtained using the standard deviation of earnings. The variable was significant at the 5 percent level in 1960 indicating that it may be a potential measure of uncertainty and an index of expected earnings. Further study may provide higher levels of measurement of uncertainty and of expected earnings.

* States which were considered as being in the regional South were: Virginia, West Virginia, North Carolina,

South Carolina, Georgia, Florida, Kentucky, Tennessee, Alabama, Mississippi, Arkansas and Louisiana.

**Twenty-nine states were considered to be on major waterways with transportation advantages. These states were: Alabama, California, Connecticut, Delaware, Florida, Georgia, Illinois, Indiana, Louisiana, Maine, Maryland, Massachusetts, Michigan, Minnesota, Mississippi, Missouri, New Hamp., New Jersey, New York, North Carolina, Oklahoma, Oregon, Pennsylvania, Rhode Island, South Carolina, Texas, Virginia, Washington and Wisconsin. 
The positive signs of the coefficients for the standard deviation imply that the more unstable the behavior of earnings in a state the more motivated were the investors to either enlarge, modernize or diversify their operation in an attempt to stabilize returns. This is consistent with the

TABLE 1

Investment Regression Equations

\begin{tabular}{|c|c|c|}
\hline & $\begin{array}{c}1959 \\
\text { Coefficients } \\
\text { (t values) }\end{array}$ & $\begin{array}{c}1960 \\
\text { Coefficients } \\
\text { (t values) }\end{array}$ \\
\hline $\mathrm{TR}_{3}$ & $\begin{array}{l}0.0761^{* * * *} \\
\quad(3.22)\end{array}$ & $\begin{array}{c}0.0695^{*} \\
(2.03)\end{array}$ \\
\hline $\mathrm{TR}_{5}$ & - & - \\
\hline $\mathrm{RR}_{3}$ & $\begin{array}{c}-0.0380^{*} \\
(-1.90)\end{array}$ & $\begin{array}{l}0.0240 \\
(1.05)\end{array}$ \\
\hline $\mathrm{RR}_{5}$ & $\begin{array}{l}- \\
-\end{array}$ & $\begin{array}{l}- \\
-\end{array}$ \\
\hline $\mathrm{SD}_{3}$ & $\begin{array}{l}- \\
-\end{array}$ & $\begin{array}{c}0.2112 * \\
(2.18)\end{array}$ \\
\hline WR & $\begin{array}{c}-0.0141^{*} \\
(-1.70)\end{array}$ & $\begin{array}{c}-0.0301^{*} \\
(-2.44)\end{array}$ \\
\hline SL & $\begin{array}{l}- \\
-\end{array}$ & $\begin{array}{l}- \\
-\end{array}$ \\
\hline ML & $\begin{array}{l}0.0000 \\
(1.03)\end{array}$ & - \\
\hline $\mathrm{K} / \mathrm{L}$ & $\begin{array}{c}-0.0018^{*} \\
(-2.12)\end{array}$ & $\begin{array}{c}-0.0002 \\
(-0.13)\end{array}$ \\
\hline$e_{k l}$ & $\begin{array}{c}-0.0008^{* * * * *} \\
(4.17)\end{array}$ & $\begin{array}{c}-0.0012 * \\
(-2.04)\end{array}$ \\
\hline $\mathrm{DE}_{3}$ & $\begin{array}{l}0.0383 * * * * \\
\quad(7.28)\end{array}$ & $\begin{array}{c}0.0290^{* * * * *} \\
\quad(4.11)\end{array}$ \\
\hline${\mathrm{S} \& \mathrm{~L}_{3}}_{3}$ & $\begin{array}{c}0.0089 * \\
(2.08)\end{array}$ & $\begin{array}{c}-0.0101^{*} \\
(-1.98)\end{array}$ \\
\hline TP & $\begin{array}{l}- \\
-\end{array}$ & $\begin{array}{l}0.0016 * * * * \\
\quad(3.84)\end{array}$ \\
\hline C & $\begin{array}{c}-0.0074 \\
(-1.35)\end{array}$ & $\begin{array}{c}-0.0183 \\
(-2.87)\end{array}$ \\
\hline S & $\begin{array}{l}- \\
-\end{array}$ & $\begin{array}{c}-0.0224 * * \\
(-2.30)\end{array}$ \\
\hline $\begin{array}{l}\text { Constant term: } \\
\text { F }\end{array}$ & $\begin{array}{c}0.0665 \\
25.1352^{* * *}\end{array}$ & $\begin{array}{l}-0.0189 \\
9.0899 * * *\end{array}$ \\
\hline $\begin{array}{l}\text { Standard error } \\
\mathbf{R}^{2}\end{array}$ & $\begin{array}{c}0.01463 \\
.8519\end{array}$ & $\begin{array}{c}0.01733 \\
.7299\end{array}$ \\
\hline
\end{tabular}

Levels of significance: $* * * *=.001, * * *=.005, * *=.01, *=.05,+=.10,-$ indicates the variables did not enter that particular model. 


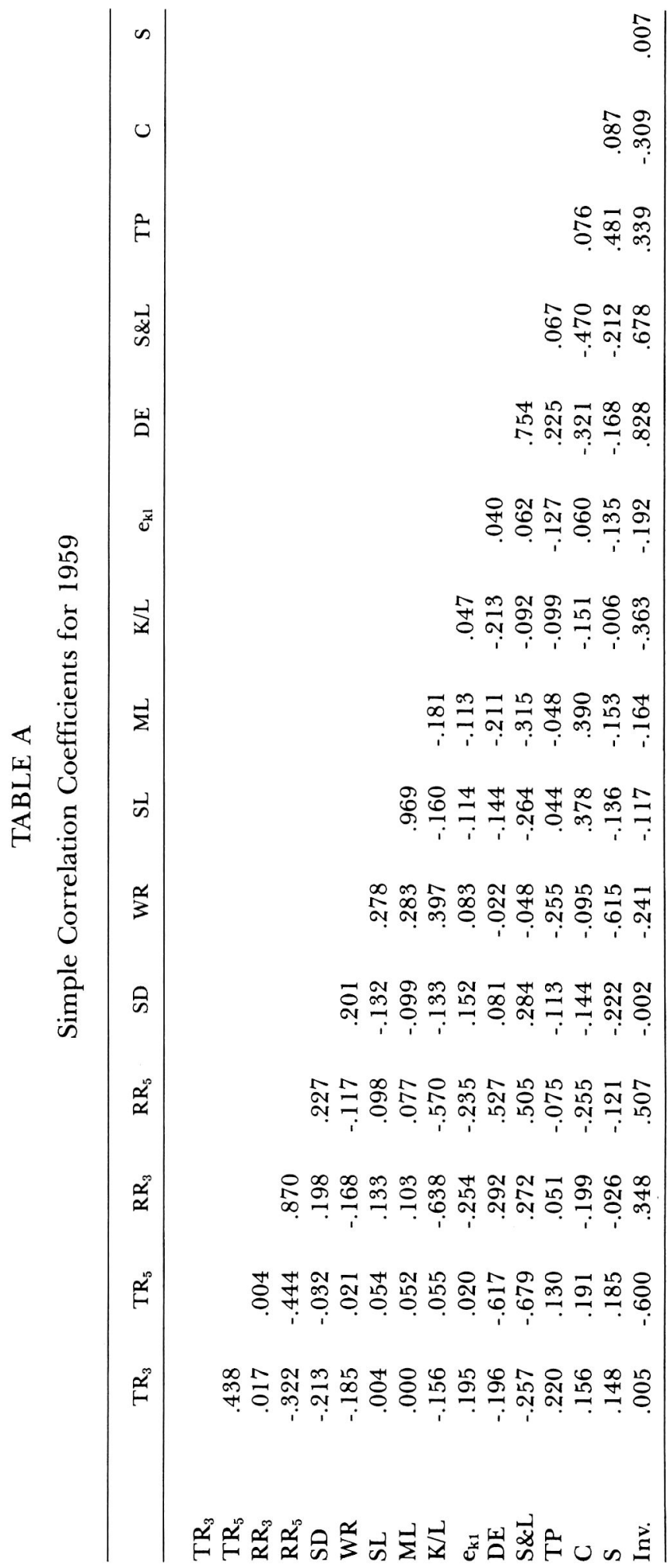


qualifying hypothesis as previously explained with reference to Sherman and Osborn [14,11].

That investment tended to occur more in low wage states is evident in the negative coefficients of the wage rates variable.

Negative signs of the capital-labor ratios and of the elasticity of capital with respect to labor agree with the theoretical reasoning that $\mathrm{K} / \mathrm{L}$ ratios tend to be equalizing. To the extent that low $\mathrm{K} / \mathrm{L}$ ratios imply low wages, these results agree with the rationale of the two previously discussed variables in which investment moves to areas of low wages which also tend to be low points of labor supply.

The switch in signs on the state and local expenditure coefficient was moderately surprising but not inconsistent with the mixed results of other empirical studies of state and local taxes. Since taxes are highly correlated to expenditures in local public sectors the $\mathrm{S}$ and $\mathrm{L}_{3}$ variable measures the negative impact of local taxes on investment decisions.

The temperature variable was highly significant in 1960. As expected, the signs were positive reflecting the effect of influential people in manufacturing preferring to work in warm climates, which agrees with Greenwood's studies.

The dummy coastal variable $(\mathrm{C})$ with its negative coefficient implies that other factors than low water transport rates were dominant in investment decisions. Assuming that states with large cities, most of which are located on major waterways, also have large supplies of non-agricultural labor, then this negative sign for the coefficient of $\mathrm{C}$ can be explained in the context of investors in manufacturing moving away from such labor supply centers where labor unions may be more common. In that respect $\mathrm{C}$ probably captures deglomeration diseconomy effects.

The dummy regional variable for South or non-South (S) with its negative sign indicates that manufacturers tended to avoid investment in the traditional Southern states in 1960. This is consistent with Scully's study of interstate wage differentials in which human capital endowments in general and educational levels in particular were lower among laborers in the South [21, pp. 767-771]. The association becomes clearer when one considers the higher skills required of labor to operate capital which embodies the latest technology.

As expected the results indicate that states with more defense expenditures than the national average experienced significantly higher investment rates than the national average. The relationship was significant at the .001 level in the 1959 and 1960 investment periods.

This is consistent with Bolton's earlier study. Defense contracts often involve new weapons and new technical processes which create the need for new capacity.

The sensitivity of the significance of profit variables to the effect of other variables in explaining investment has been studied and discussed by Eisner [17, pp. 1-29]. The role of the return variables, in fact, of all the independent variables in the investment function can be considered to be that of proxy variables for the expected rate of return $[17$, p. 26]. On the other hand, a factor not considered by Eisner, is that profits behavior may 
TABLE B

Simple Correlation Coefficients for 1960

\begin{tabular}{|c|c|c|c|c|c|c|c|c|c|c|c|c|c|c|c|}
\hline & $\mathrm{TR}_{\mathbf{3}}$ & $\mathrm{TR}_{5}$ & $\mathbf{R R}_{3}$ & $\mathrm{RR}_{5}$ & SD & WR & SL & ML & $\mathrm{K} / \mathrm{L}$ & $\mathrm{e}_{\mathrm{kl}}$ & $\mathrm{DE}$ & S\&L & $\mathrm{TP}$ & C & $S$ \\
\hline \multicolumn{16}{|l|}{$\mathrm{TR}_{3}$} \\
\hline $\mathrm{TR}_{5}$ & .544 & & & & & & & & & & & & & & \\
\hline $\mathbf{R R}_{3}$ & .109 & .308 & & & & & & & & & & & & & \\
\hline $\mathbf{R R}_{5}$ & -.228 & .004 & .919 & & & & & & & & & & & & \\
\hline $\mathrm{SD}$ & .033 & -.081 & .339 & .298 & & & & & & & & & & & \\
\hline WR & -.153 & -.157 & -.195 & -.111 & -.042 & & & & & & & & & & \\
\hline SL & -.151 & .047 & .106 & .122 & .064 & .278 & & & & & & & & & \\
\hline ML & -.160 & .020 & .073 & .096 & .124 & .283 & .968 & & & & & & & & \\
\hline $\mathrm{K} / \mathrm{L}$ & -.030 & -.092 & -.654 & -.617 & -.326 & .382 & -.161 & -.186 & & & & & & & \\
\hline$e_{k l}$ & .039 & -.126 & .030 & .042 & .101 & -.101 & -.010 & -.041 & .045 & & & & & & \\
\hline $\mathrm{DE}$ & -.106 & -.275 & .288 & .373 & .157 & -.010 & -.150 & -.224 & -.195 & .234 & & & & & \\
\hline S\&L & -.066 & -.266 & .256 & .317 & .222 & -.047 & -.272 & -.325 & -.054 & .193 & .703 & & & & \\
\hline $\mathrm{TP}$ & .119 & .246 & .087 & - -.025 & -.003 & -.267 & .045 & -.048 & -.069 & .147 & .231 & .050 & & & \\
\hline $\mathrm{C}$ & .157 & .042 & -.142 & -.211 & .086 & -.095 & .379 & .391 & -.160 & -.155 & -.321 & -.482 & .076 & & \\
\hline S & .123 & .159 & .007 & -.058 & -.097 & -.617 & -.136 & -.152 & .010 & -.022 & -.179 & -.216 & .481 & .087 & \\
\hline Inv. & .171 & .219 & .464 & .334 & .293 & -.262 & -.133 & -.181 & -.395 & .069 & .623 & .395 & .448 & -.255 & .023 \\
\hline
\end{tabular}


also serve as an indication for the supply of internal investment funds.

Eisner considered the "regressiveness" of expectations in the investment decision process in relation to past business cycles [17, pp. 27, 28]. In this framework entrepreneurs would be rational in viewing particular experiences as essentially random events from a population whose mean was thought to change slowly. If recent experiences did not conform to their expectations from past business cycles behavior, then certain variables may be considered to have temporary effects and tend to be ignored.

The implication of considering the "regressiveness" of expectations is that investment behavior is essentially a time series phenomena and complete studies in this respect should extend back over at least one, and preferably more, business cycles. Various resource limitations prevented such a time series analysis within the scope of this study.

\section{CONCLUSIONS}

The role of government spending is objectively demonstrated in the high significance (up to .001) of the respective variables. A measure of the extent of mixed economy relationship existing at that time is thereby indicated by the coefficients.

The significance of the trends and rates of earnings not only support the theory of the firm as a theoretical tool in investment explanation but also lends to ferret out policy variables, as may the significance of the standard deviation of earning and other variables. More refined research in this area of reducing uncertainty and improving the index of expected returns may improve the significance of such a variable as the standard deviation of returns.

The synthesis of several theoretical channels appears to be promising albeit not without pitfalls.

More work is planned in extending the time periods with new data and in refining the model specification in terms of pooling data, considering other forms of the data as well as of the model itself.

\section{BIBLIOGRAPHY}

\section{BOOKS}

1. Badger, Ralph E., et al. Investment Principles and Practices. Englewood Cliffs: Prentice-Hall, Inc., 1961

2. Baumol, William J. Economic Theory and Operations Analysis. Englewood Cliffs: Prentice-Hall, Inc., 1965

3. Bloom, Gordon F. and Northrup, Herbert R. Economics of Labor Relations. Homewood: Richard D. Irwin, Inc., 1969.

4. Bolton, Roger E. Defense Purchases and Regional Growth. Washington, D. C.: The Brookings Institution, 1966.

5. Borts, George H. and Stein, Jerome L. Economic Growth in a Free Market. New York: Columbia University Press, 1964.

6. Fuchs, Victor R. Differentials in Hourly Earnings by Region and City Size. Occasional Paper No. 101, National Bureau of Economic Research, 1967.

7. Fuchs, Victor R. Changes in the Location of Manufacturing in the United States Since 1969. New Haven: Connecticut: Yale University Press, 1962.
8. Hoover, Edgar M. Location Theory and the Shoe and Leather Industries. Cambridge: Harvard University Press, 1937.

9. Leabo, Dick A. Basic Statistics. Homewood: Richard D. Irwin, Inc., 1972.

10. Myrdal, Gunnar. Economic Theory and Underdeveloped Regions. London: Gerałd Duckworth, 1957.

11. Osborn, R. D. Effects of Corporate Size on Efficiency and Probability. Urbana: University of Illinois Press, 1950.

12. Reynolds, Lloyd G. Economics. Homewood: Richard D. Irwin, 1969.

13. Romans, J. T. Capital Exports and Growth Among U.S. Regions. Middletown, Connecticut: Wesleyan University Press, 1965.

14. Sherman, Howard J. Profits in the United States. New York: Cornell University Press, 1968.

$$
\text { Journal Entries }
$$

15. Brown, Murray and de Cani, John S. "A Measure of 
Technological Employment," Review of Economics and Statistics, XLV, (November, 1963), pp. 386-394.

16. Dziewonski, Kasimierz. "A New Approach to the Theory and Empirical Analysis of Location," $\mathrm{Pa}$ pers, The Regional Science Association, XVII, (1966), p. 171 .

17. Eisner, Robert. "A Distributed Lag Investmen Function," Econometrica, XXVIII, (January, 1960), pp. $78 \mathrm{ff}$.

18. Eisner, Robert and Strotz, Robert H. "Determinant of Business Investment," Impacts of Monetary Policy by the Commission on Money and Credit (1963), p. 463.
19. Eisner, Robert and Strotz, Robert H. "Planning Capital Expenditures-The Company's Future," Business Horizons, (Spring, 1958).

20. Mansfield, Edwin. "Technical Change and the Rate of Imitation," Econometrica, XXIX, (October, 1961), pp. 741-766.

21. Scully, Gerald W. "Interstate Wage Differentials: A Cross Section Analysis," American Ecomomic Review, LIX (December, 1969), p. 763.

22. Whitbeck, Volkert S. and Kisor, Manown, Jr. "A Tool in Investment Decision-Making," Financial Analyst Journal, IX, No. 3 (May-June, 1963). 